\title{
CDC25C wt Allele
}

National Cancer Institute

\section{Source}

National Cancer Institute. CDC25C wt Allele. NCI Thesaurus. Code C104135.

Human CDC25C wild-type allele is located in the vicinity of $5 q 31$ and is approximately 53

$\mathrm{kb}$ in length. This allele, which encodes $\mathrm{m}$-phase inducer phosphatase 3 protein, is

involved in mitotic control and cell cycle progression. 